\title{
The Performance and Efficiency of Zakat Institutions in Jambi
}

\author{
Desi Retnowati \\ Bogor Agricultural University
}

\begin{abstract}
Zakat is the third pillar of Islam and has socio-economic impacts. In practice, zakat institutions have limitations with regard to their institutional and managerial aspects, which result in them not achiveing optimum performance and efficiency. This research aims to analyze the performance and efficiency of zakat institutions in Jambi Province. This research measures the performance of zakat institutions through the institutional indicators of the National Zakat Index (NZI), and it measures their efficiency using the Data Envelopment Analysis (DEA) method. The samples used in this research are BAZNAS Jambi Province and LAZ RSIM. Based on the results of the performance analysis, BAZNAS Jambi had an index value of 0.44, and LAZ RSIM had an index value of 0.63, which classified the performance of the zakat institutions as "fairly good" to "good." Based on the results of the efficiency analysis, LAZ RSIM has reached the maximum level of $100 \%$ efficiency. BAZNAS Jambi Province is operating at $56.1 \%$ efficiency. The average efficiency for the combined zakat institutions is $78.1 \%$.
\end{abstract}

Keywords: performance, efficiency, national zakat index (NZI), data envelopment analysis (DEA)

\section{INTRODUCTION}

Zakat is a potential, strategic, and decisive element of worship for the development of welfare through the mechanism of income distribution. The various values contained within zakat form a strong and rational basis for the empowerment and development of people's lives. Viewed from the context of development, zakat has three main functions. First, when used as a buffer for the state budget, zakat can be used to overcome a state budget deficit. Second, zakat has a role as a social safety and welfare instrument. Third, zakat can be used to develop production in order to boost economic growth. As such, according to Beik (2009), zakat is an instrument of poverty alleviation that is used in order to create social welfare.

According to Muhammad (2002), the existence of zakat institutions is very important. Before the existence of zakat institutions, zakat was distributed by individuals and had the impact simply to alleviate cost of consumption. Through the existence of zakat institutions, zakat funds are expected to have socio-economic impacts, capable of overcome problem of poverty and encourage development of society. Zakat, as one of the productive economy sources, can thus produce maximum benefits.

Good management of zakat by institutions can mean that zakat, used as an economic instrument, has the power to alleviate poverty, open up jobs, generate income, and encourage economic growth (Muhammad, 2002). The existence of zakat institutions is expected to lead to changes in the conventional system of collection and management of zakat.

Based on the results of research by Bogor Agricultural Institute (IPB), the 
National Zakat Amil Agency (BAZNAS) and the Islamic Development Bank explained that the potential amount of national zakat in 2011 reached Rp 217 trillion, while in 2015 it amounted to $\mathrm{Rp}$ 280 trillion. These amounts are made up of zakat from households, private industry, state enterprises, and savings. As sourced from the financial statements of BAZNAS, the amount of zakat, infak, and alms collected nationally in 2015 totaled around Rp 4 trillion, or $1.4 \%$ of the potential of national zakat. This condition took place in a provincial context, specifically in Jambi. According to Wediawati (2012), Jambi Province, with a GRDP per capita above the national average, has the potential to generate zakat of Rp 35.84 billion/month, or Rp 430 billion/year. In contrast to these potential amounts, however, the actual amount of charity-funds collected in Jambi Province amounted to only $\mathrm{Rp} 8$ billion/year, or equivalent to $1.8 \%$ of the total potential of zakat funds that have been calculated.

Based on data from BAZNAS Jambi, about $\mathrm{Rp} 1.94$ billion in ziswaf funds was collected through BAZNAS Jambi in 2012, while this increased in 2016 to $\mathrm{Rp} 3.03$ billion. Thus, there is an increasing tendency for people to pay zakat funds through the zakat institutions. On the other hand, however, the number of zakat institutions (LAZ) operating in Jambi Province has also increased. Up to January 2017, the LAZ that have operated in Jambi Province and been registered, or that are in the process of licensing, through BAZNAS Jambi, are LAZ Rumah Sosial Insan Madani (RSIM), LAZ OPSEZI, LAZ DPU Daarut Tauhid, and LAZ BMH.

The sub-optimal collection and management of zakat by the zakat institutions is reflected in the gap between the potential and actual amounts of zakat that are collected. The collection and management of zakat can be enhanced through performance and efficiency improvements of the zakat institutions. Therefore, it is important to examine the performance and efficiency of zakat institutions in Jambi.

\section{LITERATURE REVIEW}

Zakat is one of the most important socioeconomic instruments in Islam. It works as a comprehensive system and was established in the 7th century. It was the first fiscal system in the world and has extraordinary set of rules such as object of zakat and its tariffs, the limits of minimal treasury which does not contain zakat (nishab), and distribution of zakat (Qardawi, 2001).

After the abjectly poor and the poor, the target of zakat is amil. Amil are those who perform zakat activities, ranging from collectors to treasurers and guards, to the accountants who carry out the entry of zakat funds that are distributed for the mustahik (Qardawi, 2001). Hafidhudin (2002) conceptually states, the tasks of amil zakat are to map muzaki and mustahik data collection, carrying out coaching, collecting and receiving zakat, and praying for muzaki when they receive zakat. In addition, the amil is expected to utilize the collected data to create a mustahik and muzaki zakat map, mapping the number, determining the steps to be taken for distribution, and conducting sustainable development.

\section{Organizational Performance and Efficiency}

Organizational performance is defined as the ability of an organization to execute tasks in order to achieve its goals in accordance with the ability it possesses and the previously laid out programs, vision, and mission. The concept of performance within the organization concerns whether or not the organization's goals have been met (Mahsun, 2006). According to Rahmatina, in PEBS (2010), from the zakat institution side, there are 
four objectives of organizational performance measurement. First, evaluate the performance of zakat institutions. Second, motivate them to improve their professionalism, accountability, and transparency. Third, create conditions that are conducive to community development. Fourth, provide guidance for donors in distributing their funds.

Efficiency is part of the economic concept. The concept of market equilibrium known as The Fundamental Theorem of Welfare Economics suggests a relationship between market balance and the concept of Pareto efficiency. Pareto efficiency, also called allocative efficiency, refers to a condition in which the allocation of goods is considered to be efficient if no one can increase their utility without reducing the utility of others (Karim, 2007).

There are three factors that lead to efficiency. First, the ability to produce a larger output with the same given inputs. Second, producing the same output with smaller amounts of the given inputs. Third, larger amounts of inputs resulting in proportionately greater quantities of output (Hidayat, 2014). According to Hadad et al. (2003), there are several approaches used to define input and output relationships in the measurement of efficiency in the financial industry. These are:

1. The production approach

2. The intermediation approach

3. The asset approach.

The incorporation of performance and efficiency analysis in this study is closely related to previous studies on similar topics regarding the performance of zakat institutions, or the efficiency of intermediary institutions. Akbar (2009) aimed to determine the relative efficiency level of zakat institutions using the Data Envelopment Analysis (DEA) approach. The outputs considered in this study were the amounts of collected and distributed funds. The input variables were personnel cost, operational cost, and socialization cost. The object of this research was nine zakat institutions, namely BAZNAS, Dompet Dhuafa, Lazis Muhammadiyah, Pos Peduli Umat, Al Falah Social Fund Foundation, Baitul Maal Foundation BRI, BNI, Rumah Zakat Indonesia, and Baitul Maal Muamalat. The approach used by Akbar (2009) to measure efficiency was the production approach, whereby the zakat institutions were assumed to be producers generating pools of funds and distributing them. As such, the results obtained in the study reflected only two aspects of zakat institution efficiency. Based on the input orientation, the sources of inefficiency are the cost of socialization and operational costs.

Lestari (2015) conducted a study on the financial performance efficiency of the East Lombok Region Amil Zakat Agency during the period 2012-2014. The input variables were collected funds, fixed assets, and employee salaries, and the output variables were distributed zakat funds and fixed assets. The use of these variables reveal that the approach used in the research was the intermediation approach, wherein it was assumed that LAZ was distributing the zakat funds to zakat mustahik.

Adnan, in Muhammad (2002) in his research, looked into financial accountability in zakat institutions in the Special Region of Yogyakarta, highlighting a number of factors that make a person willing to pay zakat. These are classified as religious factors such as faith, religious understanding, and reciprocity, and other factors such as social concern, self-satisfaction, and organization. The existence of zakat institutions, viewed from the aspect of their professionalism, seek to improve the quality of their services, such as transparency, socialization, and administration. It is considered that improvements in these areas will increase the preference of respondents to pay zakat to the institution. 


\section{RESEARCH METHOD}

This study uses both primary and secondary data. The primary data were obtained through questionnaires and interviews with representatives appointed by BAZ and LAZ. The secondary data were obtained through a literature study, internal data covering BAZNAS Jambi and LAZ RSIM in 2015 and 2016 supported by research questionnaires, and other literature. The data used in the efficiency analysis were collected funds, distributed funds, and personnel costs.

The quantitative research used two research methods. The Zakat Institutional Indicator Index in the National Zakat Index (NZI) was used to measure the performance of zakat institutions in Jambi Province, with the Data Envelopment Analysis (DEA) method used to measure the relative efficiency among zakat institutions. The data in this research were obtained using the software DEAP version 2.1 and Microsoft Excel 2007.

\section{Institutional Performance Using the NZI Method}

The performance of zakat institutions in this study was measured using the NZI Institutional Indicator Index approach. The institutional indicators have four derived variables, namely aggregation, management, distribution, and reporting. The second stage of calculating the index of each variable was performed using the following formula:

$$
\mathrm{I}_{\mathrm{i}}=\frac{\left(S_{\mathrm{i}}-\operatorname{Smin}\right)}{(\operatorname{Smax}-\operatorname{Smin})}
$$

Where:

$\mathrm{I}_{\mathrm{i}}=$ Index on variable $\mathrm{i}$

$\mathrm{S}_{\mathrm{i}}=$ actual score on measurement of variable $\mathrm{i}$

Smax $=$ Maximum score

Smin $=$ Minimum score .
The resulting index value will be in the range $0.00-1.00$. The lower the index value obtained, the worse the performance of the zakat institution. Conversely, the greater the value of the index obtained, the better the performance. A value of 0.00 is the lowest value that can be obtained for the index of institutional indicators of NZI, with 1.00 being the highest.

\subsection{0-0.20: not good performance \\ $0.21-0.40$ : less good performance \\ 0.41-0.60: fairly good performance \\ 0.61-0.80: good performance \\ $0.81-1.00$ : very good performance}

The third stage involves multiplying the index obtained for each variable with their respective weighting to obtain an index for the indicator. The Institutional Indicator Index can be measured using the following model:

$\mathrm{X}_{\mathrm{p}}=0.30 \mathrm{X}_{\mathrm{c}}+0.20 \mathrm{X}_{\mathrm{m}}+0.30 \mathrm{X}_{\mathrm{a}}+0.20 \mathrm{X}_{\mathrm{r}}$

Where:

$\mathrm{X}_{\mathrm{p}}=$ Index of Institutional Indicators

$\mathrm{X}_{\mathrm{c}}=$ Index of Variable Collection

$\mathrm{X}_{\mathrm{m}}=$ Index of Management Variable

$\mathrm{X}_{\mathrm{a}}=$ Index of Distribution Variable

$\mathrm{X}_{\mathrm{r}}=$ Index of Reporting Variable.

Measurement of Efficiency through the Data Envelopment Analysis (DEA) Method

DEA method is created to evaluate performance of organizations in this study mentioned as Decision Making Units (DMUs). The relative efficiency of a zakat institution is determined using the intermediation approach with the Constant Returns to Scale (CRS) model to give the efficiency of the distribution and the collection of inputs used. Output-oriented measurements are measured when the number of outputs can be increased proportionally without changing the number of inputs used. While inputoriented measurements are measured if 
some inputs can be reduced and still maintain a fixed output value. This analysis is based on evaluating the relative efficiency of comparable DMUs. Furthermore, efficient DMUs will form boundaries. If the DMU is at the forefront then it can be said to be efficient compared to other DMUs in the same peer group. In addition to generating efficient grades from each DMU, DEA also shows units in reference to inefficient units.

Efficiency of $D M U_{0}=\frac{\sum_{k=1}^{p} \mu_{k} \gamma_{k j}}{\sum_{i=1}^{m} v_{i} x_{i j}}$

Where:

DMU $=$ observed unit

$\mathrm{p}=$ different outputs

$\mathrm{m}=$ different inputs

$x i j=$ the number of inputs $i$ used by DMU $\mathrm{j}$

$\mathrm{ykj}=$ the number of $\mathrm{k}$ outputs generated by DMU j.
DEA is a non-parametric approach method. Therefore, it does not require an initial assumption of a production function. The assumption used is the absence of random error, with inefficiency indicated as deviation from the frontier. This study used the CRS model developed by Charnes, Cooper, and Rhodes (Model CCR) in 1978. This model assumes that the ratio of input and output additions are the same. That is, if there is an additional input of $x$ times, then the output will also increase by the same $x$ times. The approach used in this research is the intermediation approach. Referring to the Zakat Core Principles, the zakat institution is an intermediary institution. Its main function is the collection of zakat funds from muzaki and distributing them to mustahik (Beik et al., 2014).

Table 1. Variables in the Model

\begin{tabular}{cccc}
\hline Input & Variable & Output & Variable \\
\hline X1 & Personnel Cost & Y1 & Distributed Funds \\
X2 & Collected Funds & & \\
\hline
\end{tabular}

Source: Primary data (2017)

The cost of personnel referred to in this study is the cost incurred by zakat institutions to meet salaries, benefits, and incentives. The cost of socialization and promotion in this research covers the costs incurred by the zakat institution in disseminating and promoting its programs, in addition to other forms of activity through mass media, pamphlets, brochures, advertisements, direct socialization, cooperation, and others. Funds are collected in the form of zakat funds deposited by muzaki, which are then distributed in the form of funds allocated through zakat programs implemented by the zakat institutions. In this research, the data are processed using DEAP Version 2.1 and Microsoft Excel 2007.

\section{RESULTS AND DISCUSSION}

Performance Analysis of Zakat Institutions

Results of the Performance Measurement for BAZNAS Jambi

The institutional indicators on the National Zakat Index (NZI) describe the performance of zakat management institutions in collecting, managing, and distributing zakat funds and making reports on a regular basis. The performance analysis for BAZNAS Jambi is given below. 
Table 2. Measurement of Institutional Performance Variables for BAZNAS Jambi

\begin{tabular}{|c|c|c|c|c|c|}
\hline Numb. & Variable & Actual Condition & Score & Index & Performance \\
\hline 1 & Collecting & $\begin{array}{l}\text { Growth of zakat funds } \\
\text { collected is } 7.98 \% \text {. }\end{array}$ & 2 & 0.25 & Less good \\
\hline 2 & Managing & $\begin{array}{l}\text { Has a strong program, } \\
\text { future strategic future } \\
\text { planning and standard } \\
\text { operating procedures } \\
\text { (SOPs) in its activity, but } \\
\text { doesn't have ISO } \\
\text { certification. }\end{array}$ & 4 & 0.75 & Good \\
\hline 3 & Distributing & $\begin{array}{l}\text { Distributing ratio is } 59 \% \text {. } \\
\text { Socio-program in } \\
\text { consumptive form twice a } \\
\text { year. Economy-program } \\
\text { just once a year. Dakwah } \\
\text { program is } 23.51 \% \text { of funds } \\
\text { collected. }\end{array}$ & 3.25 & 0.56 & Fairly good \\
\hline 4 & Reporting & $\begin{array}{l}\text { Has financial report (not up } \\
\text { to standard). }\end{array}$ & 2 & 0.25 & Less good \\
\hline
\end{tabular}

In the aggregate variable, BAZNAS Jambi has fund growth of $7.98 \%$. The score of 2 means the growth of zakat fund accumulation is in the range 5$9 \%$ per year. The results of the index calculations reveal a less good performance.

For the Management variable, BAZNAS Jambi obtained a score of 4, which means that BAZ already has SOPs, an annual work program, and strategic plan related to the program and/or a fundraising target. Based on the score obtained, BAZNAS Jambi obtained an index value of 0.75 .

The Distribution variable contains the following derived variables: allocation to collection ratio (ACR), socialconsumptive charity program, economy program, and dakwah program. The type of economy program envisaged in the research is business capital grants for mustahik businesses, either in the form of capital goods and/or loan capital. In BAZNAS Jambi, the economy program is provided in the form of cash, for its venture capital assistance program, and business capital loans. BAZNAS operates the criterion that a program should be implemented within $12-15$ months. For the dakwah program, BAZNAS Jambi scored 5, which means that BAZNAS has distributed more than $10 \%$ of its zakat funds to dakwah programs. The amount of zakat funds distributed by BAZNAS Jambi for dakwah programs amounted to $23.51 \%$ of the total amount of zakat funds. For this variable, BAZNAS scored 3.25 , with an index value of 0.56 , which shows fairly good performance.

The last variable is the Reporting variable. BAZNAS Jambi has financial statements, but they are neither audited nor published. BAZNAS's financial statements are thus not yet in accordance with PSAK. The score for this variable is 2 , with the index value calculated as 0.25 , thus indicating a less good performance.

Based on the data that were collected and processed, BAZNAS Jambi obtained an index value of 0.44 , thus indicating a "Fairly Good Performance" for the zakat institution. 
Results of the Performance Measurement LAZ RSIM

The performance measurement results were carried out in accordance with the criteria specified. Based on Table 3, the aggregate variable describes the growth rate of zakat fund accumulation. LAZ RSIM obtained a score of 3 for this variable, which means the growth of zakat funding annually falls within the range 10 $14 \%$, with the actual value reaching
$11.39 \%$. Based on the score given for this variable, the value of the index obtained is 0.50 , which shows that performance is fairly good.

The Management variables in this method show that LAZ RSIM obtained a score of 4 , with an index value of 0.75 , meaning that the zakat institution already has SOPs, an annual work program, and a strategic plan related to the program, but it does not yet have an ISO certificate.

Table 3. Measurement of Institutional Performance Variables for LAZ RSIM

\begin{tabular}{|c|c|c|c|c|c|}
\hline Numb & Variable & Actual Condition & Score & Index & Performance \\
\hline 1 & Collecting & $\begin{array}{l}\text { Growth in amount of zakat funds } \\
\text { collected of } 11.39 \% \text {. }\end{array}$ & 3 & 0.50 & $\begin{array}{l}\text { Fairly } \\
\text { good }\end{array}$ \\
\hline 2 & Managing & $\begin{array}{l}\text { LAZ has annual work programs, } \\
\text { strategic plan related, and standard } \\
\text { operation procedures (SOPs), but } \\
\text { doesn't have ISO certification. }\end{array}$ & 4 & 0.75 & Good \\
\hline 3 & Distributing & $\begin{array}{l}\text { Distributing ratio is } 100 \% \text {. A socio- } \\
\text { program in consumptive form } \\
\text { continues every month. Economy- } \\
\text { program is just once a year. Dakwah } \\
\text { program accounts for } 10 \% \text { of the } \\
\text { funds collected. }\end{array}$ & 4 & 0.75 & Good \\
\hline 4 & Reporting & A financial report has been published. & 3 & 0.50 & $\begin{array}{l}\text { Fairly } \\
\text { good }\end{array}$ \\
\hline
\end{tabular}

Source: LAZ RSIM (2017)

The Distribution variable comprises the following derived variables: ACR, social/consumptive charity program, economic program, and dakwah program. Based on the results obtained, for the criteria of ACR, LAZ RSIM obtained a score of 5 , which means the ratio of distribution to the collection was more than or equal to $90 \%$. A social/consumptive program can include the distribution of basic food, health care, and scholarship programs in the form of distributing education funds or the provision of an allowance, or a program whose purpose is to meet the needs of daruriyat. LAZ RSIM obtained a score of 5 , which means that the program is run continuously at intervals of less than 3 months. For its economic program criteria,
LAZ RSIM delivers a program within $12-$ 15 months. At LAZ RSIM the implementation of the economic program is an annual plan in the form of a village assistance program. The village program includes villages that are targeted for agricultural and livestock development, and funds are distributed in the form of seeds and livestock assistance. The other derived variable is dakwah program, for which LAZ RSIM obtained a score of 4, with the amount of zakat funds distributed for dakwah programs ranging from 7.5 to $10 \%$. Overall, this LAZ obtained a score of 4 with an index value of 0.75 , thus indicating good performance.

For the calculation of reporting variables based on the criteria of the availability of financial statements that are 
published, audited, and with a sharia audit report, LAZ RSIM obtained a score of 3, which means it has already published financial statements but they have not been audited by public accountants, and it does not have a sharia audit report.

Based on the data collected and processed, the institutional index values are obtained according to the Zakat National Index (NZI) method. LAZ RSIM obtained an index value of 0.63 , which indicates a "Good Performance" of zakat institutions.

\section{Zakat Institutions Efficiency Measurement}

Efficiency was measured using the Data Envelopment Analysis (DEA) method. The efficiency values obtained using DEA range from 0 to 1 . An efficiency of value 1 indicates the most efficient institution in the sample over a period of time, with the efficiency values for other institutions relative to the efficient institution. The closer an institution's efficiency value is to 0 , the more inefficient the institution (Mansyur, 2012).

The DEA method is used to measure and ensure the optimal capacity of a DMU through the use of inputs in generating output. In this case, a DMU will show the condition of increasing returns to scale (IRS), CRS, or decreasing returns to scale (DRS). The efficiency measurements shown in Table 7 are the relative efficiency values for the Jambi zakat institutions obtained through the intermediation approach.

Table 4. Zakat Institutions Efficiency Measurement Results

\begin{tabular}{cccc}
\hline Zakat Institutions & $\begin{array}{c}\text { Efisiensi } \\
\text { Penyaluran }\end{array}$ & $\begin{array}{c}\text { Efisiensi } \\
\text { Rata-rata }\end{array}$ & Keterangan \\
\hline LAZ RSIM & 1.000 & 0.781 & - \\
BAZNAS Jambi & 0.561 & Irs* \\
\hline
\end{tabular}

Source: Primary Data (2017)

Based on the processed data, BAZNAS Jambi experienced inefficiency. The LAZ RSIM derives an efficiency rating of 1 for zakat fund transfers, which means that on the assumption that zakat institutions are operating at an optimum scale, LAZ RSIM can be said to be relatively efficient in distributing zakat funds. The selection of distributed funds is explained that as an intermediary institution, the task or purpose of the zakat institution is to optimize the distribution of zakat funds. The results of this study show that LAZ RSIM has reached a maximum efficiency level of $100 \%$. BAZNAS Jambi obtained a value of 0.561 , thus indicating the presence of inefficiency of input optimization to produce output. The efficiency level achieved in distributing zakat funds is $56.1 \%$; it therefore has an inefficiency level of $43.9 \%$.

Based on Table 4, BAZNAS Jambi shows a $56.1 \%$ distribution efficiency, and thus an inefficiency rate of $43.9 \%$, based on IRS information. IRS explains that with fixed inputs, zakat institutions can still increase their output capacity. This means that BAZNAS Jambi can still increase its fund distribution in order for it to be optimized. This can also be achieved by reducing the causes of inefficiency variables.

Table 5. Source of Inefficiency of BAZNAS Distribution in Jambi

\begin{tabular}{llll}
\hline Variabel Penyaluran & Nilai Awal & Nilai Disarankan & $\begin{array}{l}\text { Persentase } \\
\text { Inefisiensi }\end{array}$ \\
\hline Dana Tersalurkan $(\mathrm{O})^{*}$ & 1700816831.00 & 3031013638.00 & $43.89 \%$
\end{tabular}




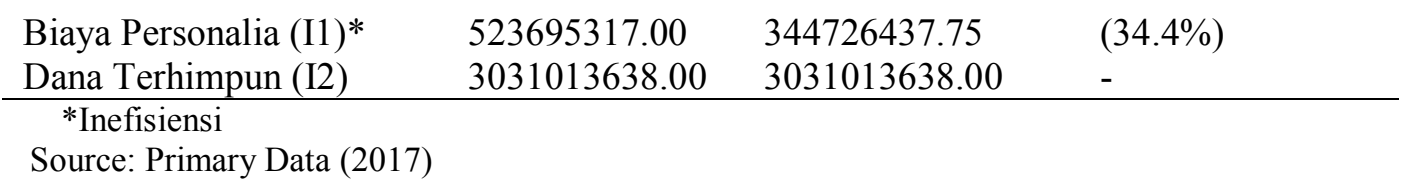

Based on Table 5, BAZNAS Jambi can improve its efficiency by optimizing its fund distribution. The efficiency achieved by BAZNAS Jambi would be better if its distribution could be increased to $43.89 \%$ of the total zakat funds collected in 2016 and exclude the zakat funds from 2015. The source of inefficiency for BAZNAS Jambi is the cost of personnel, representing an inefficiency value of $34.4 \%$. BAZNAS Jambi's efficiency can be increased by increasing the percentage of fund disbursement by $43.89 \%$ and reducing personnel cost, which is made up of a combination of wages, benefits and incentive fees, accounting for $34.4 \%$ of the total funds allocated for amil zakat. Based on these results, cost efficiency needs to be improved.

According to Fig. 1 the largest amil expense item from BAZNAS Jambi was an incentive issued for the zakat collection unit (UPZ). The key differentiator in the cost allocation of personnel/amilin costs between BAZNAS Jambi and LAZ RSIM lies in the incentives given to UPZ. BAZNAS Jambi works in cooperation with UPZ to collect zakat in some agencies. A total of $45 \mathrm{UPZ}$ from various agencies work in cooperation with BAZNAS Jambi. The UPZ incentives in BAZNAS Jambi's financial recording are included in the amilin portion.
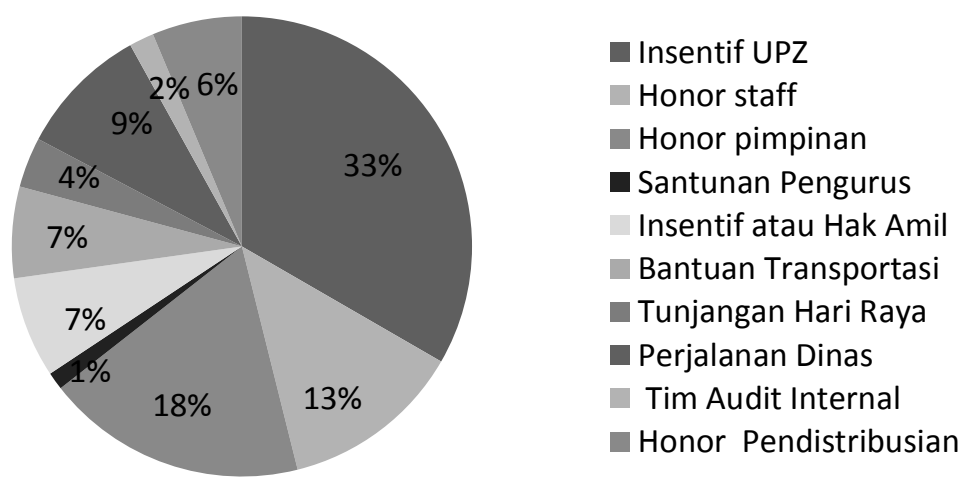

Source : BAZNAS Jambi (2017)

Figure 1. Percentage of Personnel Cost Usage

This incentive is aimed at optimizing the utilization of UPZ functions with the main objective of optimizing and improving the performance of aggregation.

This is due to the main strategy of zakat fund collection in 2016 through increased revenue from agencies, comprising both government and private sector agencies, in addition to BUMN/BUMD. So, the activities undertaken by BAZNAS Jambi to achieve its main goal is to spearhead and establish
UPZ in agencies, government agencies, the private sector, and state-owned/BUMD. The establishment of UPZ for every agency means that BAZNAS Jambi does not allocate large costs for publishing and promotion activities. Comparing the costs for BAZNAS Jambi and LAZ RSIM, it can be seen that BAZNAS Jambi has lower costs than LAZ RSIM. The respective amounts are presented in Table 6 below. 
Table 6. Promotion costs

\begin{tabular}{cc}
\hline Zakat Institutions & Promotion Cost \\
\hline LAZ RSIM & 45000000 \\
BAZNAS & 12150000 \\
\hline Source: Primary Data (2017)
\end{tabular}

The second-largest expenditure item based on Figure 1 is the honorarium. The leadership of BAZNAS Jambi consists of five people, which is in accordance with the Decree of the Minister of Religious Affairs RI No. 186 year 2016. The leadership team of BAZNAS Jambi comprises a chairman assisted by four representatives. The four representatives are engaged in the collection, distribution, and utilization of funds, financial planning and reporting, and administration and human resources. In the third position, funds' used for payment of BAZNAS Jambi's team of honor/salary, which comprises four staff members.

In economic theory, economic gain is derived from the difference between total revenue and total cost. Lower costs will result in higher economic benefits. Costs can be minimized by combining inputs in order to obtain the lowest-cost combination. The main goal of minimizing costs is to optimize earnings (Nicholson, 2002). So the purpose of cost efficiency in the organization of zakat management is to maximize the distribution of zakat funds.

BAZNAS Jambi could achieve an improvement in its relative efficiency if it were able to reduce input costs in accordance with the percentage of inefficiency and optimize the distribution of its funds. Efficiency can also be achieved by reducing personnel costs. Indeed, even when using fixed-cost input assumptions (the output approach), BAZNAS Jambi still needs to reduce personnel costs. Fundraising can be increased so that there is more optimal distribution of zakat funds.

\section{CONCLUSION AND RECOMMENDATION}

Generally, analysis of the performance of zakat institutions in collecting, managing, distributing, and reporting zakat funds reveals a fairly good to good performance. BAZNAS Jambi obtained a performance index value of 0.44 , thus indicating fairly good performance, while LAZ RSIM obtained an index score of 0.63 , which shows good performance. The variables that indicate sub-optimal performance for each of the zakat institutions are zakat collecting and reporting variables. Zakat funding has not been optimized due to the low growth of zakat funds collected. The reporting variable shows that performance is not optimal due, in general, to unpublished financial statements that are also not audited and are not produced according to the standard. Performance can be optimized by raising the accumulation of zakat funds by $15-19 \%$, or more than $20 \%$, in order to obtain an excellent performance. Transparent and accountable financial reporting is needed. Good reporting can be enhanced by the preparation of standardized, audited, and periodically published financial reports. Increased aggregation can be achieved by fostering public trust through the transparency of financial statements, operational efficiency, and program innovation.

Based on the efficiency analysis performed, LAZ RSIM achieved relative efficiency with a 100\% efficiency level, while BAZNAS Jambi recorded an efficiency value of $56.1 \%$. The distribution inefficiency that occurred in BAZNAS Jambi resulted from several factors, such as personnel costs causing input 
inefficiency, and distributed funds resulting in inefficiency of output. The zakat institution has not been efficient in managing its costs and needs to improve its efficiency by optimizing the distribution of zakat funds and reducing personnel costs, which in turn will impact

\section{REFERENCES}

Akbar, N. (2009). Analisis Efisiensi Organisasi Pengelola Zakat Nasional dengan Pendekatan Data Envelopment Analysis. Jurnal Islamic Finance \& Business Review, 4(2), 760-784.

BAZNAS Center of Strategic Studies (2016). National Zakat Index. Retrivied from: http://puskasbaznas.com/nationalzakat-index/nzi/download/72-nzi-2

BAZNAS Center of Strategic Studies (2016). Indonesia Zakat Outlook 2017. Retrivied from: http://puskasbaznas.com/outlook/in donesia-zakat-outlook-2017/69outlook-zakat-indonesia-2017english

Beik, I. S. (2009). Analisis Peran Zakat dalam Mengurangi Kemiskinan: Studi Kasus Dompet Dhuafa Republika. Jurnal Pemikiran dan Gagasan, 2(1), 1-15.

Beik, I. S., in Nursechafia, Muljawan, D., Yumanita, D., Fiona, A., \& Nazar, J. K. (2014). Towards an Establishment of Efficient and Sound Zakat System [Working Group Paper].

Beik, I. S., \& Arsyianti, L. (2016). Measuring Zakat Impact on Poverty and Welfare Using CIBEST Model. Jurnal Islamic Monetary Economics and Finance, 1(2), 141-160. . (2015). Ekonomi Pembanguanan Syariah. Bogor(ID): IPB Press.

[BPS] Badan Pusat Statistik (2017). Jumlah Distribusi Pengeluaran, on the performance of the institution. From a macro perspective, there needs to be zakat regulation from the local government in order to accumulate zakat funds to be optimized and for the performance of zakat institutions to be improved.

Persentase Penduduk Miskin dan Garis Kemiskinan, 2012-2016. Badan Pusat Statistik, Jakarta

[BPS] Badan Pusat Statistik. 2017. Jumlah Penduduk Miskin dan garis kemiskinan. PDRB Provinsi Jambi. Pertumbuhan Ekonomi Provinsi Jambi. Badan Pusat Statistik, Jambi

Coelli, T. J., Rao, D. S. P., O’Donell, C. J., \& Battese, G. E. (2005). An Introduction to Efficiency and Productivity Analysis. New York, NY: Springer Science + Business Media.

Firdaus, M., Beik, I. S., Irawan, T., \& Juanda, B. (2012). Economic Estimation and Determinations of Zakat Potential in Indonesia (IRTI Working Paper Series WP 1433-07, August).

Hadad, M. D. (2003). Analisis Efisiensi Industri Perbankan Indonesia: Penggunaan Metode Non Parametrik Data Envelopment Analysis (DEA). Research Paper no 7/5. Biro Stabilitas Sistem Keuangan Bank Indonesia.

Hadad, M. D., Hall, M. J. B., Kenjegalieva, K., Santoso, W., Satria, R., \& Simper, R. (2008). Efficiency in Indonesian Banking Recent Evidence. (WP 2008-08). ISSN 1750-4171.

Hafidhudin, D. (2002). Zakat dalam Perekonomian Modern. Jakarta (ID): Gema Insani.

Hafidhudin, D., \& Rahmat Pramulya. (2008). Kaya Karena Berzakat. Jakarta (ID): Raih Asa Sukses

Hasibuan, S. P. (2008). Organisasi dan Motivasi. Jakarta(ID): Bumi Aksara 
Hidayat R. 2014. Efisiensi Perbankan Syariah Teori dan Praktik. Bekasi (ID): Gramata Publishing

Karim, A., A. (2007). Ekonomi Makro Islam. Jakarta (ID): Raja Grafindo Persada. 2007. Ekonomi Mikro Islam. Jakarta (ID): Raja Grafindo Persada.

Lestari, A. (2015). Efisiensi Kinerja Keuangan Badan Amil Zakat Daerah (BAZDA): Pendekatan Data envelopment Analysis (DEA). Jurnal Ekonomi dan Studi Pembangunan, 16(2), 177-187.

Mahsun, M. 2006. Pengukuran Kinerja Sektor Publik. Yogyakarta (ID): BPFE Yogyakarta

Mansyur, F. 2012. Analisis Perbandingan Efisiensi BUS dan BUK Di Indonesia Menggunakan Metode SFA. UIN Sunan Kalijaga Yogyakarta. Research Report.

Muhammad (2002). Zakat Profesi: Wacana Pemikiran Zakat dalam Fiqih Kontemporer. Jakarta (ID): Salemba Diniyah.

Nicholson, W. (2002). Mikroekonomi Intermediate dan Aplikasinya. Jakarta (ID): Erlangga.

PEBS UI, CID (2009). Zakat dalam Pembangunan: Era Baru Zakat MenujuKesejahteraan Umat. Jakarta: PEBS UI dan CID.
PEBS UI, IMZ (2010). Indonesia Zakat Development Report: Menggagas Arsitektur Zakat Indonesia. Jakarta (ID): PEBS UI dan CID.

Qardawi Y. 2001. Hukum Zakat. Jakarta (ID) : Litera Antarnusa

Rusydiana, A. S. (2013). Mengukur Tingkat Efisiensi dengan Data Envelopment Analysis (DEA): Teori dan Aplikasi. Bogor(ID): Smart Publishing.

Wahab, N. A, \& Rahman R. A. (2012). Efficiency of Zakat Institutions in Malaysia : An Application of Data Envelopment Analysis. Jurnal Economic Cooperation and Development, 33(1), 95-112.

Wediawati, B. (2012). Revitalisasi Filantropi Islam di Kota Jambi. Jurnal Penelitian Universitas Jambi, 14(1), 37-46

Desi Retnowati

Bogor Agricultural University

Indonesia

desiretnowati1995@gmail.com 